\title{
The Significance of Bioturbated Inclined Heterolithic Stratification in the Southern Part of the Miocene Solimoes Formation, Rio Acre, Amazonia Brazil
}

\author{
MURRAY K. GINGRAS \\ Department of Geology, University of New Brunswick, P.O. Box 4400, Fredericton, \\ New Brunswick E3B 5A3, Canada \\ MATTI RÄSÄNEN \\ Department of Geology, University of Turku, Turku FIN-20500, Finland
}

ALCEU RANZI

Department of Palaeontology, Universidade Federal do Acre, Bairro Distrito Industrial Caixa Postal 500, Rio Branco, Acre, Brazil

PALAIOS, 2002, V. 17, p. 591-601

Sedimentary models that apply to the Middle Miocene succession in Amazonia are controversial. Although tidally-influenced sedimentary deposits have been described from several locations, the identification of brackish-water or marine facies has been hampered by limited outcrop exposure. Also, ichnological data largely have been ignored.

This study focuses on ichnological and sedimentological relationships observed in outcropping strata of the Solimoes Formation (Middle Miocene) along the Acre River in western Brazil and northern Bolivia. The studied strata comprise a fine-grained lower unit that is sharply overlain by dipping, interbedded sands and muds, known as inclined heterolithic stratification (IHS). The IHS is present throughout the length of the outcrop, about $80 \mathrm{~m}$. The outcropping strata are interpreted to represent two depositional subenvironments: (1) A lower unit that resulted from sediment accumulation in a shallow, restricted, subaqueous depositional environment. The deposit ultimately became emergent with subsequent paleosol development. (2) An upper unit dominated by marginal marine point-bar deposits that developed in a channel. Trace fossils observed in the upper unit provide evidence that mesohaline waters occupied the channel at the time of sediment accumulation. This is supported most strongly by the presence of Scolicia, a common marine trace fossil, and reburrowed (composite) Ophiomorpha. The resultant ichnofabric represents a response to sedimentary events that demonstrates the IHS beds reflect seasonal or annual cyclicity.

The analysis of the river-exposed outcrop at Boca de Santa Pedro, Brazil, leads to four conclusions: (1) the IHS exposed in the upper portion of this deposit are possibly tidally influenced and almost certainly accumulated in a brackish-water channel; (2) if IHS are bioturbated, their temporal significance can be assessed; (3) seasonal fluctuations in discharge were significant enough to alter depositional and biological processes in this paleochannel, and; (4) brackish-water incursion into Amazonia during the Middle Miocene can be traced as far south as northern Bolivia.

\section{INTRODUCTION}

Recently, several studies have attempted to characterize the nature of sediment accumulation in Miocene Amazonia (Fig. 1), a geographical area that is defined roughly by the Amazon River drainage basin and includes parts of Brazil, Peru, Columbia, and Bolivia. Depositional models have varied from fluvial to lacustrine, and brackish/tidally influenced settings. The databases for these studies were derived from sedimentologic, microfossil, isotopic, and ichnologic analyses. Although a definitive depositional model for the Miocene of Amazonia (henceforth Miocene Amazonia) has yet to be determined, it is clear that Miocene strata in that basin represent an exceedingly complex depositional system. Those complexities are revealed partly in Rebata et al. (2000) where it is suggested that Miocene deposition in the area of Iquitos, Peru (Fig. 1), occurred in a large, tidally influenced sea that was at times openly connected to marine waters in the north. Furthermore, the observed sedimentological succession provided evidence that basin waters were strongly layered, accommodation space was limited, depositional dip was shallow, and subsidence was induced repeatedly.

Although a body of geochemical evidence (derived from shelly fauna; Vonhof et al., 1998) contradicts the presence of a marine-influenced embayment in Miocene Amazonia, it is proposed in Gingras et al. (2000), and in this study, that those data are the result of the sedimentological complexities suggested for the Miocene invagination. In particular, the shelly fauna represent backshore lagoonal and lacustrine deposits that were reworked and incorporated into the sedimentary pile upon transgression. It also must be accepted that, at times, the embayment water was essentially fresh.

Geologically, most of the previous research associated with Miocene Amazonia has focused on determining the general nature of the ancient paleoenvironments therein. Detailed sedimentological studies that attempt to determine the nature and style of sedimentation in the context of ichnological analysis are rare. However, a few detailed sedimentological studies have been presented. For example, Räsänen et al. (1995) documented the presence of tid-

0883-1351/02/0017-0591/\$3.00 


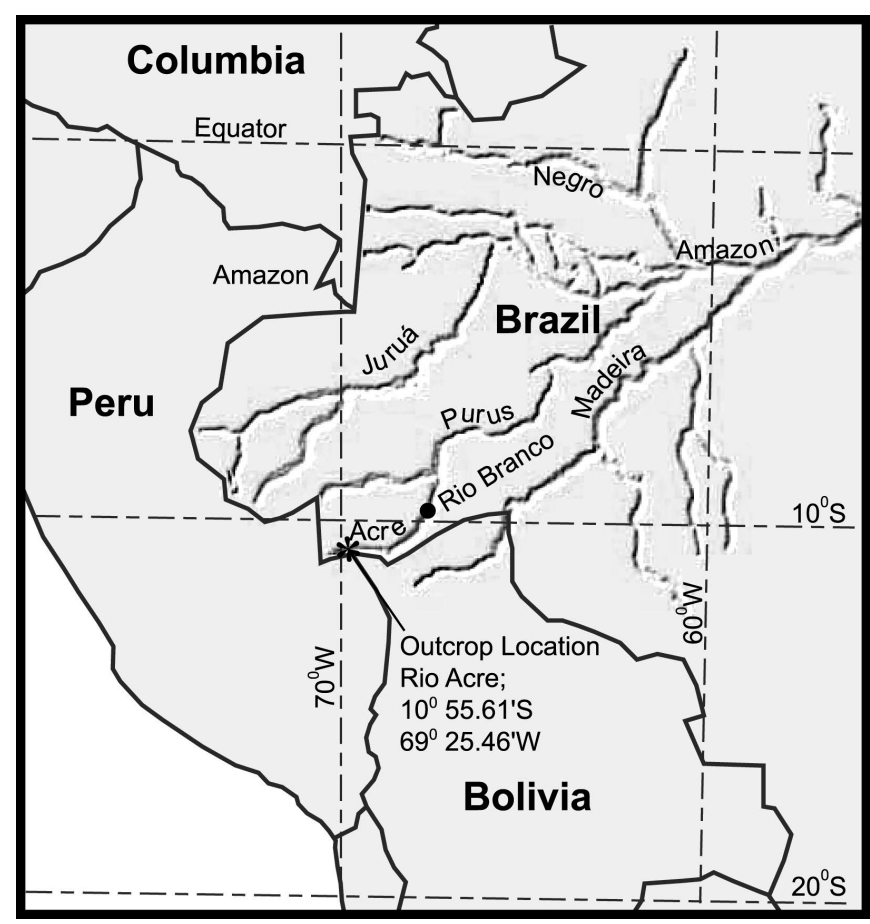

FIGURE 1- Location map. The study area, major rivers, and the Iquitos/Nauta area are shown.

ally influenced strata near Rio Branco, Brazil (Fig. 1). Rebata et al. (2000) and Räsänen et al. (1998) provide abundant evidence of tidally influenced deposition near Nauta, Peru (Fig. 1). Also, Honikoski (2002) provides a synthesis of the sedimentology and ichnology of the Iquitos / Nauta corridor in Peru (Fig. 1).

The outcrop presented herein represents the most southerly tidally influenced, marginal marine strata as yet reported from Miocene Amazonia. Its presence provides strong evidence that Miocene incursion reached at least as far south as northern Bolivia (the studied outcrop occurs along the Acre River, which represents the political boundary between Brazil and Bolivia in the area). Detailed analysis of the outcrop is aimed at achieving two objectives: (1) to contribute to the overall sedimentological understanding of Miocene Amazonia, and; (2) to provide a parsimonious interpretation that explains the nature of sediment accumulation locally.

\section{Study Area}

This study is based on outcropping strata of the Solimoes Formation (Middle Miocene) that occur along the Acre River $\left(10^{\circ} 55.61^{\prime} \mathrm{S}, 69^{\circ} 25.46^{\prime} \mathrm{W}\right)$, which defines the Brazil/Bolivia border in the area (Fig. 1). At the study locality, Boca de Santa Pedro, the riverbank exposure is 9 to $12 \mathrm{~m}$ high and it offers good, locally fresh exposure. The strata comprise a fine-grained lower unit that is sharply overlain by dipping, interbedded sand and mud that, henceforth, are referred to as "inclined heterolithic stratification," or IHS (after Thomas et al., 1987). The dipping IHS is present throughout the length of the outcrop, over a distance of about $80 \mathrm{~m}$. In general, the outcrop is exposed from about $2 \mathrm{~m}$ above river level, which was at low stage during the study.

\section{Ichnological Studies in the Miocene of Amazonia}

The only studies dedicated to the integration of ichnology to sedimentological datasets in Miocene strata in Amazonian have focused on the Pebas Formation (Gingras et al., 2000; Honikoski, 2002; Rebata et al., 2000), which represents the age equivalent strata several hundred $\mathrm{km}$ to the north, in Peru (Fig. 1). Although these studies represent a notable contribution to the paleogeographic understanding of Miocene Amazonia, they cannot be related directly to the outcrops reported herein. Understanding the depositional similarities between the two areas is exceptionally important, however, as the extent of Middle Miocene brackish-water incursion into Amazonia is not yet established.

All of the previous ichnological studies to the north strongly have supported the hypothesis that the Miocene embayment contained brackish water, and at times, had a nearly marine character (Gingras et al., 2000; Honikoski, 2002; Rebata et al., 2000). The primary evidence supporting this was the presence of a comparatively cosmopolitan ichnofauna that locally included Ophiomorpha, Scolicia, Chondrites, Thalassinoides, and Arenicolites. Those studies also reported a preponderance of tidal sedimentary structures including sediment couplets, neap-spring bundles, current reversal features, reactivation surfaces, and pinstripe lamination.

Ichnological data largely have been ignored by previous studies in the Acre area. Based on sedimentological data, Räsänen et al. (1995) reported tidally influenced IHS from equivalent strata near Rio Branco, $60 \mathrm{~km} \mathrm{NE}$ of the present study. Ichnological data combined with detailed sedimentary observations will help expand on previous interpretations, or generate new hypotheses pertaining to the nature of the sedimentary environments.

The interpretations presented herein rely partly on previous characterizations of brackish-water ichnofauna in tidally influenced depositional settings, which are described in Pemberton et al. (1982). For a broader view, MacEachern et al. (1992) provide a detailed ichnological model for Cretaceous shoreface deposits of the Western Canadian Sedimentary Basin. Modern analogues and a detailed analysis of brackish-water fauna are presented in Gingras et al. (1999).

\section{Inclined Heterolithic Stratification}

The term "inclined heterolithic stratification" was formalized by Thomas et al. (1987). Semantically, the term is purely descriptive and applied to concordant sets of inclined beds that display pronounced lithological heterogeneity. The inclination of the beds must reflect depositional dip, thereby structurally inclined beds are not IHS.

Thomas et al. (1987) diligently note the various depositional settings in which IHS might occur. Prominent among these are tidal settings, in particular on tidally influenced point bars. Since that publication, IHS has been associated increasingly with tidally influenced, marginal marine deposits (Smith, 1989; Ranger and Pemberton, 1992; Räsänen et al., 1995; Falcon-Lang, 1998; Witzke et 
al., 1999; Gingras et al., 1999). Although it is widely accepted that IHS is exceedingly common in mesotidal marginal marine settings, the origin of the mud/sand interbeds still generates debate. In general, due to the common presence of IHS in tidal settings, it is intuitive that the interbeds result from diurnal or semidiurnal tidal rythmicity. However, even with $\mathrm{cm}$-scale interbeds, the perceived sedimentation rates would be anomalously high. Furthermore, IHS beds deposited in brackish water settings commonly preserve trace fossils, suggesting that in those instances sedimentation rates are not extraordinary. Also, some authors have suggested that marginal marine IHS simply reflect the shifting of the turbidity maximum due to fluctuations of continental discharge (Smith, 1989; Gingras et al., 1999).

\section{METHODS}

The primary dataset consists of sedimentological and ichnological data gathered through detailed logging of the outcrop. The sedimentary texture, sedimentary structures, nature of bedding and bedding contacts, fossil content, and lateral variability were documented. Ichnological observations concentrated on the identification of ichnogenera, the degree of bioturbation, the distribution of ichnofossils and ichnofossil assemblages, and their physical interrelationships. A limiting factor regarding data collection was the unlithified nature of the sediment. This made it difficult to observe bedding planes and was a hindrance to the identification of ichnogenera.

Some of the ichnological data were collected subjectively, for example: (1) the degree of bioturbation varies from unbioturbated to completely bioturbated, and; (2) trace fossils are sporadically distributed, intercalated, or present in characteristic ichnofossil assemblages that bioturbate specific bedding horizons. Other data, specifically trace fossil size and depth of penetration, were derived from averages of field measurements (generally $n=5$ to 10) or represent a maximum observed size or depth of penetration.

\section{DESCRIPTION OF THE SEDIMENTARY DEPOSITS}

\section{General Outcrop Description}

Throughout the observable extent of the exposure, a massive-appearing, crumbly, reddish brown, muddy stratum is overlain by IHS that is described in detail, below. The IHS beds are comprised of red/purple mud and tan colored sands; their apparent dip is East (Fig. 2).

Separating the lower unit from the IHS is a sharp contact over which is a discontinuous, up to $3 \mathrm{~cm}$ thick, pebble lag. The contact is slightly undulatory and trends upwards in the westernmost $30 \mathrm{~m}$ of the outcrop (Fig. 2).

Most of the IHS beds can be traced laterally across the outcrop. They are continuous; however, they locally grade from sand to mud, or apparently bifurcate into discrete beds (Fig. 2). Along the western part of the exposure, the beds are approximately concordant with the contact. Across the remainder of the outcrop, the IHS beds downlap onto the scoured surface, where they are brecciated or deformed along the point of contact. In some instances, the IHS is undeformed and simply pinches out horizontally
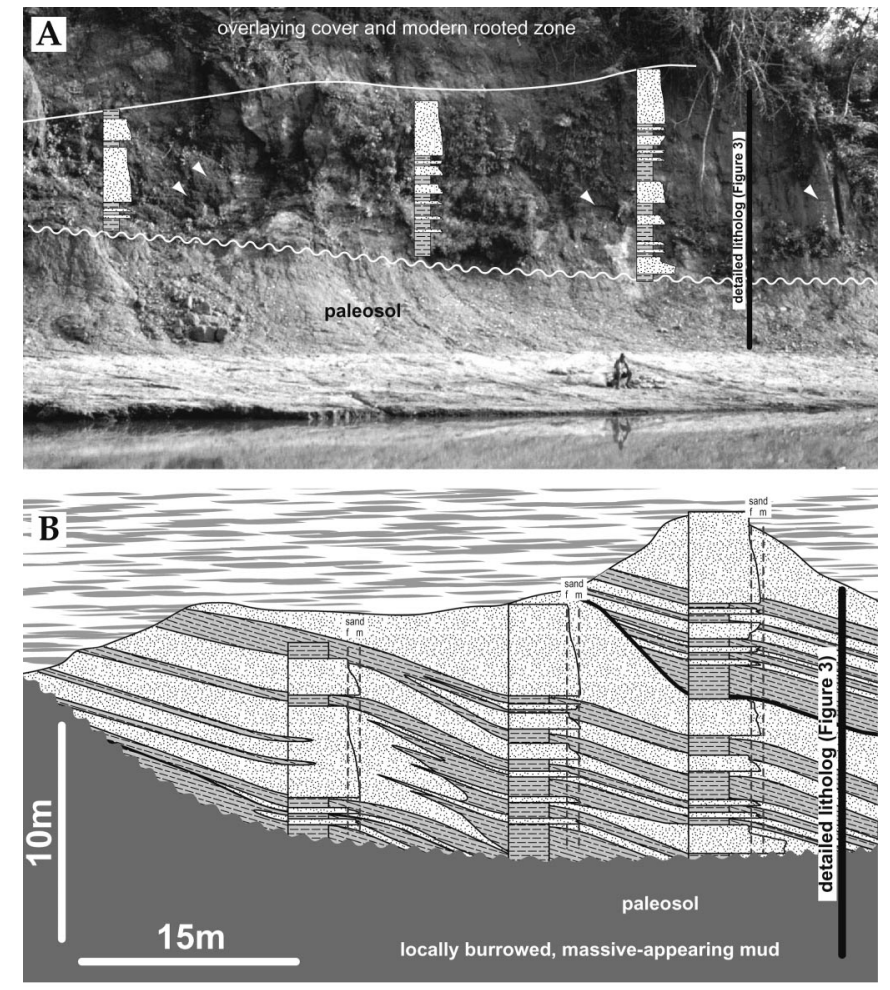

sand interbeds in IHS $\square$ fine grained lower stratum
sands in IHS $\quad$ overlaying cover and modern rooted zone

FIGURE 2-Photograph and schematic interpretation of the studied section. (A) Photograph of the section. The white arrows indicate poorly-defined inclined heterolithic stratification (IHS). (B) Schematic view of the outcrop showing the interrelationships between the inclined heterolithic stratification (IHS) beds and the underlying paleosol. The beds were mapped by tracing them individually (clearing some cover where necessary). Note the second set of IHS in the upper right of the schematic. Here it is seen that the sand / mud beds grade laterally and locally appear to bifurcate.

along the contact. The easternmost part of the outcrop contains another sharp contact that cuts into a thicker inclined sand bed. Another set of IHS beds reside in that scour; regarding lithology, bed thickness, sedimentary structure, and dip angle they are like the underlying inclined beds.

\section{The Sedimentary Succession}

The sedimentary succession at Boca de Santa Pedro consists of lightly bioturbated (ichnofabric index 1 to 3 ), locally massive-appearing mud that grades into massive, rooted mud. These fine-grained strata are sharply overlain by 2 sets of IHS that are separated by a sharp burrowed contact (Figs. 2, 3).

The base of the striplog (Fig. 3) is defined as $0.0 \mathrm{~m}$. However, the base was $1.1 \mathrm{~m}$ above the river level, which was low at the time of study. Because the river level fluctuates markedly, there is no rationale to adjust the reported striplog elevations to a river datum. Therefore, the unadjusted measurements are retained. 


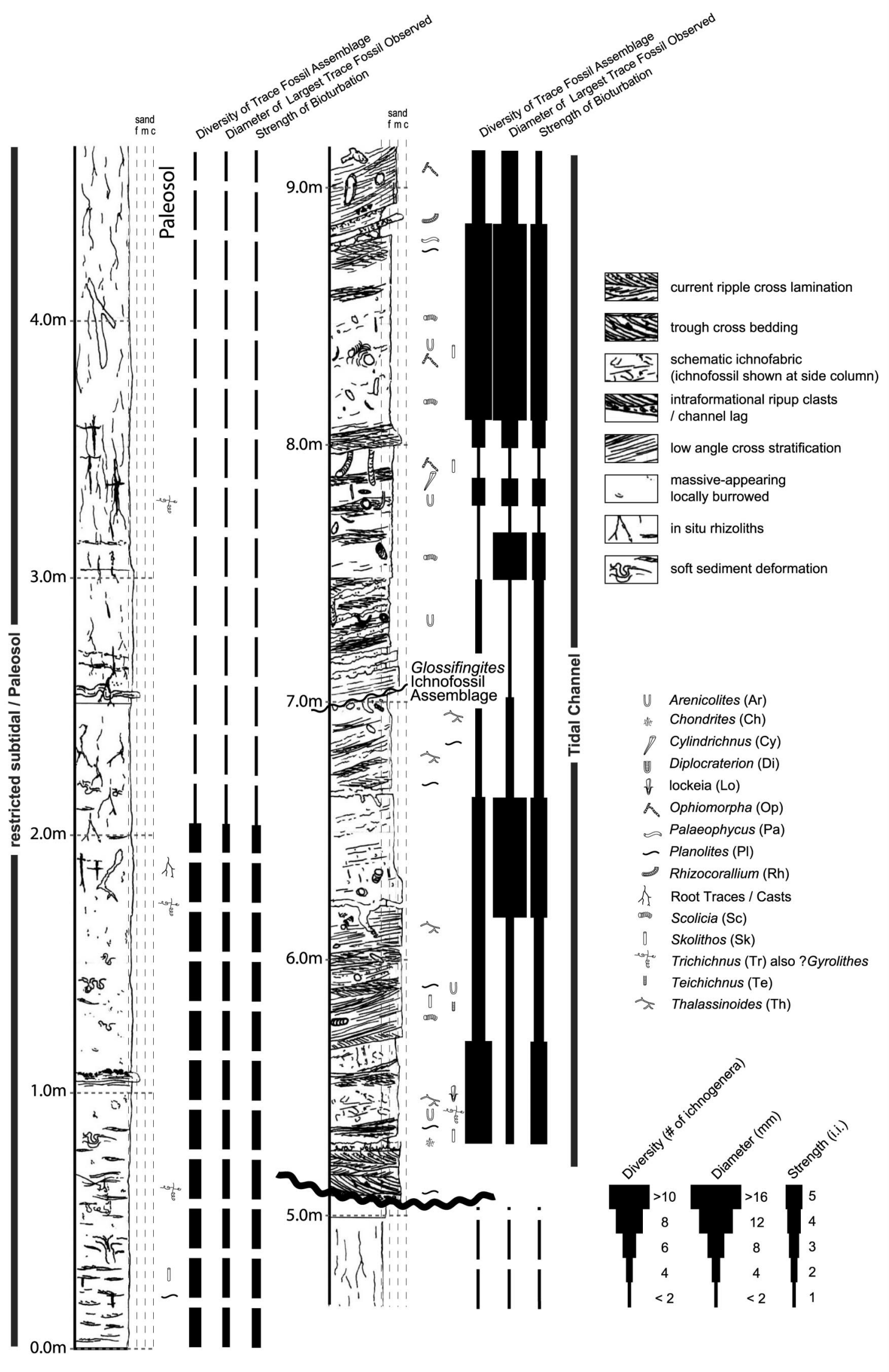

FIGURE 3-Detailed strip log from Boca de Santa Pedro, Brazil. The location of the strip log is shown in Figure 2. 


\section{0 to $1.1 \mathrm{~m}$}

Between 0.0 and $1.1 \mathrm{~m}$, the stratum is dominated by a brown to reddish brown, locally massive-appearing mud. However, starved current ripples and rare convolute laminae are present that are characterized by well sorted, fine and very fine sand. The lenticular starved ripples decrease in abundance upwards, whereas convolute lamination is increasingly common upwards. At $0.7 \mathrm{~m}$, low angle crosslamination is present. The cross-lamination is defined by lenticular, curvilinear laminae sets that locally scour into each other.

In this lower unit, very little organic detritus is preserved, but evidence of infaunal biogenic activity is readily observed. Skolithos, Planolites, and ?Trichichnus comprise the ichnofossil assemblage. The Skolithos are 3 to $4 \mathrm{~mm}$ in diameter and extend about $8 \mathrm{~cm}$ below their bedding juncture origin. Skolithos normally descend from starved ripples and are sand-filled; Planolites are mud-filled. Here, the Planolites are comparatively small, generally $2-3 \mathrm{~mm}$ in diameter. They are observed only in the muddy substrate. The ?Trichichnus are very slender (about $1 \mathrm{~mm}$ diameter) and extend downward 15-20 cm from their point of origin. The burrows locally branch and their taxonomy is uncertain.

\section{1 to $5.1 \mathrm{~m}$}

At $1.1 \mathrm{~m}$, a thin, low angle cross-laminated sand bed is present. Abundant intraformational ripup clasts are present within and on top of the sand bed. Above the thin sand, the mud, which lies sharply in contact with the sand, has a more massive appearance and redder color (Fig. 4A). However, some sedimentary structure can be discerned, including convolute bedding defined by rare sand laminae within the mud. The massive mud grades upwards into rooted mud near $1.8 \mathrm{~m}$. Between 1.8 and $5.1 \mathrm{~m}$, the rooted fabric is increasingly dominant and it obliterates most of the sedimentary structure. Only rare convolute sand laminae are observed (2.2 and $2.6 \mathrm{~m})$. Near $3.1 \mathrm{~m}$, a 1-cm-thick layer of bedded gypsum is present. Small gypsum crystals are abundant and pedogenic slickenslides are common above the gypsum. Several types of rhizoliths are present from 3.1 to $5.1 \mathrm{~m}$; (1) large, intraclast-filled, crudely conical cavities with green (chemically reduced) clay around their margins; (2) fibrous to branching rhizoliths with Mnoxide halos (Fig. 4B), and; (3) thin, branching rhizoliths with green (chemically reduced) halos in the surrounding sediment (Fig. 4B). The rhizoturbation continues upwards to the contact with the IHS unit; the intensity of root penetration increases upwards.

Besides the rhizoliths, the only other trace fossils present are small Planolites and ?Trichichnus, similar to those described above. They are observed only between level 1.1 and $1.8 \mathrm{~m}$, are sporadically distributed, and rare.

\section{1 to $7.0 \mathrm{~m}$}

Near $5.1 \mathrm{~m}$, a sharp, slightly undulatory contact truncates the rooted, muddy bed (Fig. 4C). A discontinuous pebble lag, up to $3 \mathrm{~cm}$ thick, overlies the contact. Several intraformational ripup clasts, lithologically identical to the underlying unit, also are observed. Most of the clasts are less than $1 \mathrm{~cm}$ (longest axis), but a few exceed $2 \mathrm{~cm}$ in maximum dimension.

Between 5.2 and $7.0 \mathrm{~m}$, the stratum consists of inclined, interbedded, locally highly burrowed mud and sand. Bed thickness for both lithologies ranges between 30 and 80 $\mathrm{cm}$. The ratio of sand to mud is about $1: 1$.

The sand beds have sharp bases, but their upper contacts are bioturbated completely. Generally the sand interbeds are fine grained, well sorted, and show little or no grading. Several primary sedimentary structures repeatedly appear, the most conspicuous of these is trough crossstratification, which is normally present immediately above the lag or contact (Fig. 4C). Small ripup clasts are common on the cross-bed foresets. Trough cross-bedding is observed only rarely in sand beds that do not sit directly on the contact. Current ripples and climbing current ripples are common in all of the sand beds (Fig. 4E). The ripple foresets normally are draped by mud flasers, less commonly by organic detritus. Flasers commonly are observed as couplets. Current reversal features are recorded in the strata $(5.15 \mathrm{~m})$. Ripple foresets generally dip to the SW; however, several ripple sets indicate sediment transport towards the NE. Small intraformational ripup clasts are common throughout the sandy facies. Finally, the sand beds are stained orange by iron oxide. Black manganese oxide is common around ripup clasts and organic detritus.

Sand interbeds range between unburrowed and thoroughly bioturbated, but unburrowed and lightly burrowed (i.i. 2) sand are dominant. Where the degree of bioturbation is low, observed trace fossils include rare Skolithos, Planolites, and Thalassinoides (Fig. 4F). The trace fossils are sporadically distributed and moderately sized (5-10 $\mathrm{mm}$ diameter). All three ichnogenera may have thin mud linings. Locally, the degree of bioturbation is high. In those instances, the ichnofossils are lined with mud derived from the mud interbeds, and the fossil burrows clearly descend from the muddy horizons. Because of their association with the muddy beds, the highly burrowed sandy facies is discussed below in the context of the mud interbeds.

The mud interbeds have burrowed lower contacts and sharp, undulatory upper contacts. Much of the finegrained strata is composed of sandy silt. However, clay interbeds (up to $20 \mathrm{~cm}$ thick), comprising about $10 \%$ of the fine interbeds, and cm-scale sand beds are present. Because this facies is normally highly bioturbated, physical sedimentary structures are usually absent. Exceptions to this include common current ripples (restricted to the minor sand interbeds) wherein foresets normally are draped by organic or mud flasers. Centimeter-scale convolute bedding is also common. Finally, the mud beds are stained purple and red, whereas green reduction halos surround certain ichnofossils.

Mud interbeds are highly to completely bioturbated (i.i. 4 to 5). Bioturbation is most intense near sedimentary (mud/sand) interfaces, and a diverse suite of trace fossils is observed. Skolithos and Planolites are the most commonly observed trace fossils. They are 3 to $8 \mathrm{~mm}$ in diameter, and are ubiquitous. Nearly as common are large-diameter (up to $20 \mathrm{~mm}$ ), thickly walled Ophiomorpha that descend through the mud into the sand beds. Locally, the Ophiomorpha wall is intensely reburrowed by Palaeophycus/Planolites (Fig. 4E), and the initial physical character (i.e., the 

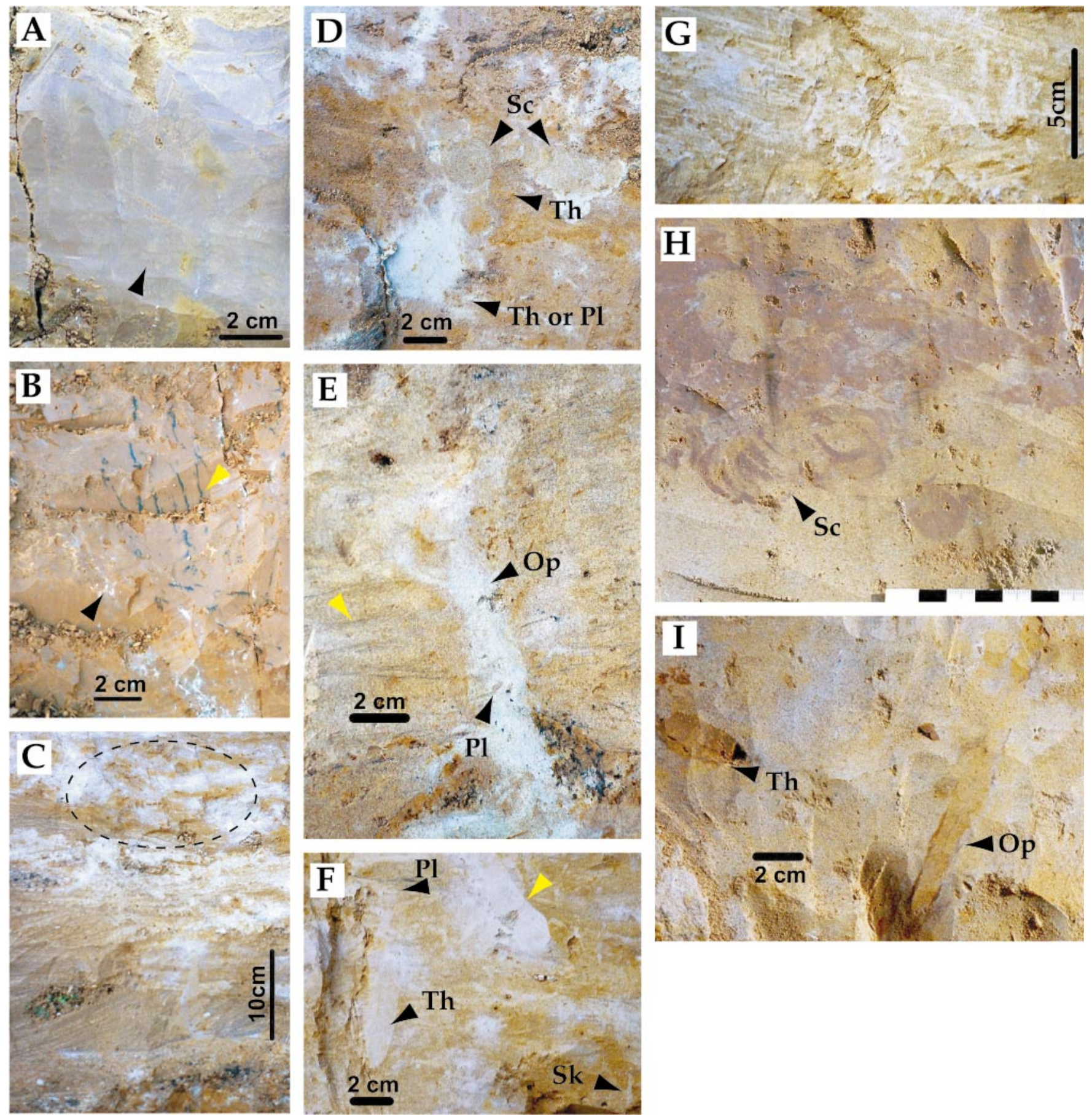

FIGURE 4-Selected Facies from Boca de Santa Pedro. Elevations refer to Figure 3. (A) 1.3m: Locally burrowed, massive-appearing mud. Arrow indicates Planolites mottling. (B) $4.4 \mathrm{~m}$ : Rhizoliths in massive-appearing mud. Note that some root casts are black with Mn oxide (yellow arrow), whereas others have a reduced (black arrow) halo. (C) $5.1 \mathrm{~m}$ : Contact between lower and upper unit. Here, trough cross-stratification sits above the contact. It grades upward into low angle and ripple cross-laminated sand. The upper third of the picture is burrow-mottled with Planolites-reburrowed Ophiomorpha (dashed ellipse). (D) 5.6m: Scolicia (Sc) reworking a silty sand in the location of a preexisting Ophiomorpha-like trace fossil. Thalassinoides (Th) and Planolites (PI) also cross cut the Ophiomorpha. (E) 6.1m: The very edge of an Ophiomorpha $(\mathrm{Op})$ is exposed, thereby showing only the Planolites-reburrowed (PI) Ophiomorpha lining. The Ophiomorpha are generally completely reburrowed and the lining is not always well-preserved (see 4I). (F) 7.0m: Thalassinoides (Th), Planolites (PI), and Skolithos (Sk). (G) 7.1m: Low angle cross-laminated to parallel-laminated sand. (H) $7.6 \mathrm{~m}$ : Well preserved Scolicia. (I) $9.0 \mathrm{~m}$ : Ophiomorpha nodosa, in which the wall mammalations are still preserved. 
mammalations) of the lining has been ruined. Some beds are bioturbated completely by reburrowed Ophiomorpha, lending a mottled appearance to the beds. In those instances, the bioturbated nature of the sediment is not evident except upon close inspection (upper part of Fig. 4C). However, Ophiomorpha do not represent the final phase of substrate colonization in these beds. Rare, similarly sized Thalassinoides crosscut the Ophiomorpha (Fig. 4F), and Scolicia, 15 to $28 \mathrm{~mm}$ in diameter, crosscut Ophiomorpha and Thalassinoides (Fig. 4D). Scolicia is most abundant in association with Ophiomorpha and at mud/sand interfaces. The trace fossil is dominantly bedding plane parallel, but vertical movement is locally documented. Teichichnus locally crosscut all of the aforementioned trace fossils. The Teichichnus reported herein have a causative burrow similar to Thalassinoides and represent the protrusive, truncated burrow walls of the latter ichnofossil. Other rarely observed trace fossils include Arenicolites, Diplocraterion, and bivalve equilibrichnia.

\section{0 to $9.1 \mathrm{~m}$}

At $7.0 \mathrm{~m}$, a sharp, slightly undulatory contact erosionally cuts into the underlying IHS. A Glossifungites-demarcated discontinuity denotes the contact between the underlying and overlying IHS sets (Figs. 2, 3). The ichnofauna is composed solely of 10 to $18 \mathrm{~mm}$ diameter branching Thalassinoides suevicus that extend $20 \mathrm{~cm}$ into the underlying deposit. The burrows are unlined and filled with sediment derived from the upper unit.

Between 7.0 and $9.1 \mathrm{~m}$, the stratum consists of inclined, interbedded, locally highly burrowed mud and sand. Bed thickness for both lithologies ranges between 30 and 80 $\mathrm{cm}$. The ratio of sand to mud facies is about 1:2.

Sedimentologically and ichnologically, this unit is almost identical to the previously described 5.1 to $7.0 \mathrm{~m}$ interval. Low angle cross-bedded (Fig. 4G) and current ripple laminated sands, and highly bioturbated mud and sandy mud (Fig. 4H, I), are the dominant facies.

\section{INTERPRETATION AND DISCUSSION}

\section{Interpretation}

The outcropping strata are interpreted to represent two depositional subenvironments: (1) A lower unit that resulted from sediment accumulation in a shallow, restricted, subaqueous depositional environment. The deposit ultimately became emergent, subsequently a paleosol developed obscuring palimpsest sedimentary fabrics. (2) An upper unit characterized by marginal marine IHS that developed in a channel, the base of which is demarcated by an erosional discontinuity.

\section{Interpretation, 0.0 to $1.1 \mathrm{~m}$}

The muddy texture of the lowermost unit suggests that sedimentation was primarily from suspension. Abundant starved current ripples evidence intermittent traction transport of coarser sediment. Low angle cross-lamination at $0.7 \mathrm{~m}$ may be the result of gentle wave reworking. Abundant convolute bedding probably resulted from coarser sediment loading thixotropic mud; however, seis- mic disturbance, degassing, and dewatering can all generate similar fabrics.

A relatively stressed ichnofossil assemblage comprising Planolites, Skolithos, and ?Trichichnus is consistent with subaqueous sediment accumulation. Similar trace fossil assemblages have been reported from lacustrine and brackish-water settings (Gingras et al., 1999a; Mangano et al., 2000). In consideration of the physical sedimentary structures, the simplest interpretation is that sedimentation occurred in a restricted, shallow lagoon or lacustrine system.

\section{Interpretation, 1.1 to $5.1 \mathrm{~m}$}

Between 1.1 and $5.1 \mathrm{~m}$, the basal stratum is progressively more massive-appearing, heavily rooted, and gypsum rich. This unit is initiated by a sharp-based sand bed and ripup clast horizon. Low angle cross-lamination in the sand likely was produced by waves. Because the sand bed is thin and continuous, it is not thought to be the result of channelized erosion and deposition. Also, the ripup clasts indicate that the underlying unit was consolidated or semiconsolidated (dewatered) before the sand bed was emplaced. It is suggested that the sand bed represents an event deposit that eroded into the preexisting lagoon / lake deposits and induced a change in the system's configuration. Thereafter, the deposit shoaled, became emergent, and was colonized by terrestrial plants. The high degree of alteration, abundant roots, and diversity of root types imply that exposure was prolonged. The development of bedded gypsum and gypsum crystals can be related to seasonal evaporitic conditions. The pervasive reddish brown color of the sediment probably is due to the presence of oxidized surface or ground water that oxidized iron and adsorbed iron in the fine-grained media.

Simply stated, this unit indicates that the area became emergent and a paleosol developed. Although the length of time the area was exposed is indeterminate, the well-developed root traces, and the presence of pedogenic slickenslides, point to protracted exposure.

\section{Interpretation, 5.1 to 7.0 to $9.1 \mathrm{~m}$}

The gentle undulation and upwards-ramping character of the erosional surface are best associated with channel erosion. This is supported by the presence of IHS above the discontinuity that normally is preserved in point-bar deposits, especially in tidal settings (Thomas et al, 1987; Smith, 1989). A thin, discontinuous channel lag is the result of coarse sediment transport along a channelized axis, and abundant, angular ripup clasts (Fig. 4C) possibly were derived from cut-bank margins. The angular character of the clasts indicates that the underlying stratum was consolidated by the time channel erosion occurred.

The overlying IHS result from extreme contrasts in the caliber of sediment that accumulated in the immediate area. Trough cross bedding and current ripples show that the sand beds were delivered primarily by traction; however, climbing current ripples received part of the sand from suspension. The sharp-based sand beds are erosional and their emplacement occurred during abrupt, energetic sedimentary events. Suppressed bioturbation in the sand is due to high sedimentation rates and rapidly shifting 
substrates. Also, other physicochemical stresses, such as fluctuating salinity and low oxygenation, may have influenced the burrowing infauna. Although no clear tidal sedimentary structures are present, rare herringbone crosslamination, abundant flasers, and common mud couplets show that tidally-influenced sediment deposition cannot be discounted (Gastaldo et al., 1993). The tops of the sand beds are bioturbated completely by trace fossils associated with the mud beds (see below).

Although the mud in the fine-grained interbeds might have settled from suspension, several authors have shown that once fine-grained sediment has flocculated, it exhibits hydrodynamic behavior more akin to grains of sand (Johnson, 1983; van Leussen and Cronelisse, 1992; Lick, 1994; Stone and Droppo, 1994). Thus, it is not necessarily correct to surmise that hydraulic energy was substantially lower at the time of mud and silt accumulation. But, given the high degree of bioturbation originating in the mud beds, it is reasonable to suggest that when those sediments were accumulating, sedimentation rates were comparatively low, and thereby hydraulic energy probably was subdued.

Sedimentologically, the trace fossils in this unit are epigraphic (an inscription cut in stone) and provide detailed information of the sedimentary system. (1) The observed ichnological assemblage suggests mesohaline waters occupied the channel at the time of the IHS deposition. This is supported most strongly by the presence of Scolicia, a marine trace fossil made by echinoids ( $\mathrm{Fu}$ and Werner, 2000; also see Discussion). Other trace fossils, including reburrowed Ophiomorpha (both Ophiomorpha and composite trace fossils are virtually absent in fresh water systems; Gingras et al., 2000), and eurhythmic (harmoniously proportioned) Thalassinoides are only common in brackish- to marine-waters. (2) The resultant ichnofabric (Fig. 5) demonstrates the IHS beds reflect seasonal or annual cyclicity. In other words, given the repetitive nature of complex infaunal recruitment, it is unlikely that such a complex fabric would be produced in a short time frame (Fig. 5). Furthermore, echinoids are notoriously sensitive to their surrounding physicochemical environment (Irlandi et al., 1997; Basuyaux et al., 1998; Metaxas, 1998; Fu and Werner, 2000), and extreme changes that deliver undesirable substrate and water conditions to the urchin's habitat would be inhospitable to the animal. (3) If the infaunal mortality rate is high during the deposition of sand beds, recolonization during ambient conditions must be partly through larval recruitment. For many echinoids, larval recruitment is a well-defined annual occurrence (Pedrotti, 1993). Notably, larval recruitment patterns are highly dependant on basin circulation patterns and, in tid- al systems, tidal exchange (Morgan et al., 2000; Moser and McIntosh, 2001).

Because of the similarities shared between the upper and lower IHS units, they are both thought to have developed under tidally influenced conditions in brackish (mesohaline) water. The sand beds are envisaged to have accumulated during times of high continental (fluvial) discharge; their lower degree of bioturbation and comparatively stressed trace fossil suite support an influx of fresh water. Mud beds were deposited during times of lower fluvial discharge and reflect more stable marginal marine conditions.

A Glossifungites ichnofossil assemblage demarcates the contact between the upper and lower IHS. The Glossifungites ichnofacies consists of burrow architectures and sedimentological relationships consistent with burrowing into a firm substrate. The widespread exposure of firm (compacted) sediment requires erosion of previously buried sediment due to changes in local base level. Such changes are attributed most commonly to fluctuations in sediment supply, subsidence, autocyclic avulsion (such as delta-lobe abandonment), or eustatic adjustment (Frey and Seilacher, 1980; Pemberton and Frey, 1985; Pemberton and MacEachern, 1995; Savrda, 2001). In this case, given the lack of mappable data, the upper IHS is interpreted to represent autocyclic channel infilling. As the channel complex infilled, locally, erosion partly exhumed the underlying, consolidated IHS.

\section{DISCUSSION}

\section{The Temporal Significance of Inclined Heterolithic Stratification}

As noted above, the temporal nature of IHS is not well understood. In fact, no previous attempts have been made to assess the temporal significance of tidal IHS in the rock record. However, this study illustrates the potential of applying ichnology to assess the temporal nature of sand/ mud beds inherent in these systems.

Considering the trace fossil assemblage observed in the IHS, it is immediately apparent that a complex ichnofabric, such as that illustrated in Figure 5, developed over a longer period of time than a single tidal cycle. In fact, similar fabrics in modern environments result from slow sedimentation rates and extended exposure of the substrate to burrowing infauna. Furthermore, the relatively impoverished sand interbeds contain no observed escape traces, and all observed bioturbation extends downwards from the mud interbeds. This results from eradication of the ambient (mud-dwelling) infauna during periods of sand

FIGURE 5-Ichnological succession from IHS beds at Boca de Santa Pedro. (A) Large diameter, thickly lined Ophiomorpha that descend into the sand beds. (B) The burrow lining is reburrowed by Palaeophycus and Planolites, destroying the mammalated lining. Mud accumulation resumes on the sand deposit. (C) Ophiomorpha are crosscut by similarly sized Thalassinoides. These situations are rare. Mud still accumulates at the water/sediment interface. (D) Scolicia crosscut Ophiomorpha and Thalassinoides. A good example of this relationship is shown in 4D. (E) Sand deposition is re-established, inducing Thalassinoides and Teichichnus, which locally crosscut all of the aforementioned trace fossils. (F) Summary photo of the ichnofabric (bioturbate texture). Thalassinoides (Th) and Planolites (PI) crosscut Ophiomorpha (Op). This photograph represents the state of colonization represented in $5 \mathrm{C}$. (G) Summary photograph of the ichnofabric. Teichichnus (Te) and Planolites (PI) crosscut Ophiomorpha (Op). This photograph represents the state of colonization represented in $5 E(5 D$ is epitomized by the photo, 4D). (H) Summary photograph of the ichnofabric. Teichichnus (Te) and Thalassinoides (Th) crosscut high angle stratification. This photograph also represents the schematic $5 \mathrm{E}$. 


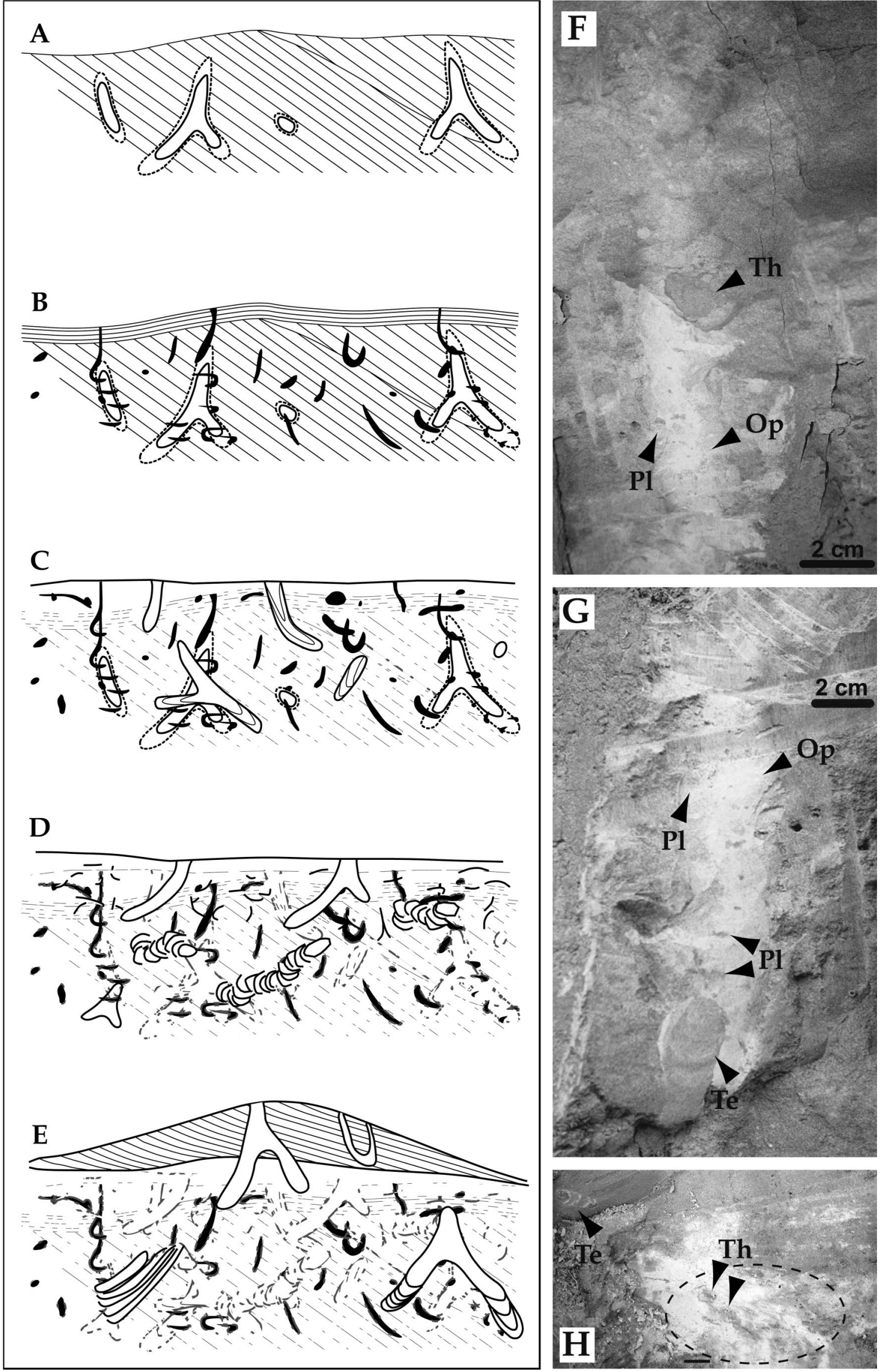


transport. Therefore, the moderately diverse assemblage observed in the mud interbeds reflects recolonization of the site upon the return of ambient conditions. Providing that even part of the burrowing community is delivered as planktonic larvae, at least a year would be required to bring larvae through their juvenile stages to reestablish the tiered, burrowing community. All of the aforementioned considerations suggest that the minimum cyclicity represented by the described IHS is annual.

\section{Paleoenvironmental Significance of the Trace Fossil Assemblage}

High degrees of bioturbation, low diversity of ichnofossils, and a preponderance of infaunal trophic-generalists of a marine affinity are all characteristics of the brackishwater model articulated by Pemberton et al. (1982). These tenets are borne out in the previously described Solimoes ichnofossil assemblage. The presence of Scolicia, however, suggests that at least mesohaline waters occupied the channel at the time of the IHS deposition. This is because, at least since the Mesozoic, fresh-water-intolerant irregular echinoids are known to be the producers of Scolicia (Seilacher, 1986; Fu and Werner, 2000). Fu and Werner (2000) show that Scolicia is best preserved where there is little competition from other burrowers in the deeper tiers, where silt or very fine sand are present in the substrate, or where bioturbation occurs at sedimentary interfaces. All of these criteria are met in these Miocene deposits in Amazonia.

Other trace fossils, including reburrowed Ophiomorpha, are common in brackish- to marine-waters. Unlike Scolicia, Ophiomorpha has been reported from a few nonmarine settings; however, such reports are comparatively rare. Some of those occurrences have been disputed, as in Goldring and Pollard (1995). Notably, reburrowed (composite) Ophiomorpha are reported only from marine strata. Although an explanation has not been put forward, it is possible that this is due to a fundamental difference between nonmarine and marine Ophiomorpha; the walls of nonmarine Ophiomorpha generally consist of rolled silt balls that do not necessarily have a fecal origin (like those shown in Loope and Dingus, 1999), whereas marine Ophiomorpha sometimes contain fecal pellets pressed into the burrow lining (Frey et al., 1978).

Given the likely marine affinity of the described ichnofacies, it is evident that sporadic marine incursion extended at least as far south as northern Bolivia. This trace fossil evidence extends the limits of known brackish-water incursion $400 \mathrm{~km}$ further south than previously established, and it supports the earlier report of Räsänen et al. (1995) that suggested that tidally influenced IHS are present in the area of Rio Branco, Brazil.

\section{CONCLUSIONS}

The analysis of the river-exposed outcrop at Boca de Santa Pedro, Brazil, leads to four key conclusions:

(1) The IHS exposed in the upper portion of this section are possibly tidally influenced and almost certainly accumulated in a brackish-water channel.

(2) If IHS beds are bioturbated, their temporal signifi- cance can be assessed. In this example, sand/mud interbeds represent seasonal or annual depositional patterns.

(3) Seasonal fluctuations in discharge were significant enough to severely alter depositional and biological processes in this paleochannel.

(4) Brackish-water incursion into Amazonia in the Middle Miocene can be traced as far south as northern Bolivia.

Further research pertaining to the Miocene of Amazonia should focus on resolving three issues: (1) integrating the growing geological dataset to establish a more precise spatio-temporal framework; (2) determining the regional extent of Middle Miocene incursion into Amazonia; and (3) developing depositional models to explain the unusual depositional patterns observed in these Miocene strata.

\section{ACKNOWLEDGMENTS}

Gratitude is extended to the Academy of Finland (project numbers: 42760, 45923) and Natural Sciences and Engineering Research Council of Canada (research grant to MKG) for their financial support. Also, we would like to thank Ian Armitage for capable field assistance. George Pemberton, Tom Saunders, Jason Lavigne, and James MacEachern made significant conceptual contributions regarding the temporal nature of bioturbated IHS. Vivienne Robertson assisted with editing and writing. The editors of PALAIOS, Drs. Gastaldo, and Savrda and two anomynous reviewers significantly improved the manuscript.

\section{REFERENCES}

Basuyaux, O., Mathieu, M., and Day, C., 1998, Effects of salinity on diet and growth of the sea urchin Paracentrotus lividus and the abalone Haliotis tuberculata: Bulletin de la Societe Zoologique de France, v. 123, p. 141-150.

FALCON-LANG, L.H., 1998, The impact of wildfire on an Early Carboniferous coastal environment, North Mayo, Ireland: Palaeogeography, Palaeoclimatology, Palaeoecology, v. 139, p. 121-138.

FrEY, R.W., and SEILACHER, A., 1980, Uniformity in marine invertebrate ichnology: Lethaia, v. 13, p. 183-207.

Frey, R.W., HowARD, J.D., and PryOR, W.A., 1978, Ophiomorpha; Its morphologic, taxonomic, and environmental significance: Palaeogeography Paleoclimatology Palaeoecology, v. 23, p. 199-229.

FU, S., and WeRnER, F., 2000, Distribution, ecology and taphonomy of the organism trace Scolicia, in northeast Atlantic deep-sea sediments: Palaeogeography Paleoclimatology Palaeoecology, v. 156, p. 289-300.

Gastaldo, R.A., Allen, G.P., and Huc, A.Y., 1995, The tidal character of fluvial sediments of the modern Mahakam River delta, Kalimantan, Indonesia: in Flemming, B.W., and Bartholomae. A., eds., Tidal signatures in modern and ancient sediments: Special Publication of the International Association of Sedimentologists 24, p. 171-181.

GINGRAS, M.K., RÄSÄNEN, M.E., and PEMBerton, S.G., 2000, Ichnological evidence for marine and marginal marine deposition in the Miocene Pebas Formation, Peru: International Association of Sedimentologists, Regional Meeting, Mar del Plata, Argentina, Abstracts.

Gingras, M.K., Pemberton, S.G., Saunders, T.D.A., and Clifton, H.E., 1999, The ichnology of modern and Pleistocene brackish-water deposits at Willapa Bay, Washington: Variability in estuarine settings: PALAIOS, v. 14, p. 352-374.

GoldRING, R., and PollaRD, J.E., 1995, A re-evaluation of Ophiomorpha burrows in the Wealden Group (Lower Cretaceous) of southern England: in Batten, D.J., ed., A tribute to Professor P. Allen, FRS; Part 1: Academic Press. London, United Kingdom, Cretaceous Research. 16, p. 665-680. 
HoNIKOSKI, J., 2002, Sedimentology, Ichnology and Sequence Stratigraphy of Four Outcrops from the Early-Late Miocene Pebas Formation, Western Amazonian Foreland Basin, Peru: Unpublished Masters Thesis, University of Turku, Finland, $94 \mathrm{p}$.

IRLANDI, E., MACIA, S., and SERAF, J., 1997, Salinity reduction from freshwater canal discharge: Effects on mortality and feeding of an urchin (Lytechinus variegatus) and a gastropod (Lithopoma tecum): Bulletin of Marine Science, v. 61, p. 869-879.

JoHnson, L.R., 1983, The transport mechanisms of clay and fine silt in the north Irish Sea: Marine Geology, v. 52, p. 33-41.

LICK, W., 1994, The flocculation, deposition, and resuspension of finegrained sediments: in DePinto, J.V., Lick, W., and Paul, J.F., eds., Transport and transformation of contaminants near the sediment-water interface: Lewis Publishers, Boca Raton, p. 35-57.

Loope, D.B., and Dingus, L., 1999, Mud-filled Ophiomorpha from Upper Cretaceous continental redbeds of southern Mongolia; an ichnologic clue to the origin of detrital, grain-coating clays: PALAIOS, v. 14, p. 451-458.

MACEACHERN, J.A., and PEMBERTON, S.G., 1992, Ichnologic aspects of Cretaceous shoreface successions and shoreface variability in the Western Interior Seaway of North America: in Pemberton, S.G., ed., Applications of Ichnology to Petroleum Exploration: SEPM Core Workshop Notes 17, p. 57-84.

Mangano, G.M., Buatois, L.A., Xiantao, W., Junmin, S., and GuoCHENG, Z., 2000, Triassic lacustrine sedimentation from the Tanzhuang Formation, Jiyuan-Yima Basin, Southeastern China: in Gierlowski-Kordesch, E.H., and Kelts, K.R., eds., Lake basins through space and time: American Association of Petroleum Geologists Studies in Geology 46, p. 133-140.

MetaXAs, A., 1998, The effect of salinity on larval survival and development in the sea urchin Echinometra lucunter: Invertebrate Reproduction and Development, v. 34, p. 323-330.

Morgan, L.E., Wing, S.R., Botsford, L.W., Lundquist, C.J., and DiEHL, J.M., 2000, Spatial variability in red sea urchin (Strongylocentrotus franciscanus) recruitment in northern California: Fisheries and Oceanography, v. 9, p. 83-98.

Moser, S.M., and MAcInTosh, D.J., 2001, Diurnal and lunar patterns of larval recruitment of Brachyura into a mangrove estuary system in Ranong Province, Thailand: Marine Biology, Berlin, v. 138 , p. 827-841.

Pedrotti, M.L., 1993, Spatial and temporal distribution and recruitment of echinoderm larvae in the Ligurian Sea: Journal of the Marine Biological Association of the United Kingdom, v. 73, p. 513530.

Pemberton, S.G., and Frey, R.W., 1985, The Glossifungites Ichnofacies: Modern examples from the Georgia coast, U.S.A.: in Curran, H.A., ed., Biogenic Structures: Their Use in Interpreting Depositional Environments: SEPM Special Publications No. 35, p. 237259.

Pemberton, S.G., and MacEachern, J.A., 1995, The Sequence Stratigraphic Significance of Trace Fossils: Examples from the Cretaceous foreland basin of Alberta, Canada: in VanWagoner, J.C., and Bertram, G.T., eds., Sequence Stratigraphy of Foreland Basin Deposits: American Association of Petroleum Geologists Memoir 64, p. 429-475.

Pemberton, S.G., Flach, P.D., and Mossop, G.D., 1982, Trace fossils from the Athabasca oil sands, Alberta, Canada: Science, v. 217, p. $825-827$.

RANGer, M.J., and Pemberton, S.G., 1992, The sedimentology and ichnology of estuarine point bars in the McMurray Formation of the Athabasca oil sands deposit, northeastern Alberta, Canada: in Pemberton, S.G., ed., Applications of Ichnology to Petroleum Exploration: SEPM Core Workshop Notes 17, p. 401-421.

RÄSÄNEN, M.E., LiNNA, A.M., SANTOS, J.C.R., and NEGRI, F.R., 1995 Late Miocene tidal deposits in the Amazonian foreland basin: Science, v. 269, p. 386-390.

RÄSÄNEN, M.E., LinNA, A.M., IRION, G., ReBATA, H.L., VARGAS, H.R., and Wesselingh, F., 1998, Geologia y geoformas de la zona de Iquitos: in Kalliola, R., and Flores, P.S., eds., Geoecologia y desarrollo Amazonico; estudio integrado en la zona de Iquitos, Peru: Turun Yliopiston Julkaisuja, Sarja A 2, Biologica, Geographica, Geologica, v. 114, p. 59-137.

REBATA, H.L., GINGRAS, M.K., and RÄSÄNEN, M.E., 2000, Sedimentology and ichnology of subtidal deposits, Nauta Formation, NW Amazonia, Peru: International Association of Sedimentologists, Regional Meeting, Mar del Plata, Argentina, abstracts

Savrda, C.E., KraWinkel, H., McCarThy, F.M.G., and McHugh, C.M.G., 2001, Ichnofabrics of a Pleistocene slope succession, New Jersey margin; relations to climate and sea-level dynamics: $\mathrm{Pa}-$ laeogeography Palaeoclimatology Palaeoecology. v. 171, p. 41-61.

SEILACHER, A., 1986, Paleontological studies on turbidite sedimentation and erosion: Journal of Geology, v. 70, p. 227-234.

SMITH, D.G., 1989, Comparative sedimentology of mesotidal (2 to 4m) estuarine channel point bar deposits from modern examples and ancient Athabasca oil sands (Lower Cretaceous), McMurray Formation: in Reinson, G.E., ed., Modern and ancient examples of clastic tidal deposits; a core and peel workshop: Canadian Society of Petroleum Geologists, Calgary, p. 60-65.

STONE, M., and DropPo, I.G., 1994, Flocculation of fine-grained suspended solids in river continuum: in Olive, L.J., Loughran, R.J., and Kesby, J.A., eds., Variability in stream erosion and sediment transport: International Association of Hydrological Sciences Publication, v. 224, p. 479-489.

Thomas, R.G., Smith, D.G., Wood, J.M., Visser, J., CalverlyRANGE, E.A., and Koster, E.H., 1987, Inclined heterolithic stratification; terminology, description, interpretation and significance: Sedimentary Geology, v. 53, p. 123-179.

VAn Leussen, W., and Cronelisse, J.M., 1992, The role of large aggregates in estuarine fine-grained sediment dynamics: in Mehat, A.J., ed., Nearshore and estuarine cohesive sediment transport: Australasian Institute of Mining and Metallurgy, Parkville, Victoria, Australia, Pacific Rim Congress 42, p. 75-91.

Vonhof, H.B., Wesselingh, F.P., and Ganssen, G.M., 1998, Reconstruction of the Miocene western Amazonian aquatic system using molluscan isotopic signatures: Palaeogeography Paleoclimatology Palaeoecology, v. 141, p. 85-93.

Witzke, B.J., Ludvigson, G.A., White, T.S., and Brenner, R.L., 1999, Marine-influenced sedimentation in the Dakota Fm, Cretaceous (Albian-Cenomanian), central U.S.; Implications for sequence stratigraphy and paleogeography in the Western Interior: Geological Society of America, Abstracts With Program, v. 31, p. 425.

ACCEPTED MAY 3, 2002

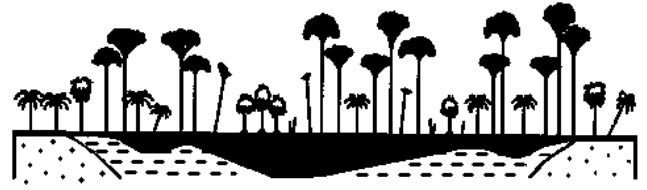

